\title{
Effects of a Concurrent Training Protocol on Body Composition and Phase Angle in Physically Inactive Young Women: A Quasi-Experimental Intervention Study
}

Efectos de un Protocolo de Entrenamiento Concurrente sobre la Composición Corporal y el Ángulo de Fase en Mujeres Jóvenes Físicamente Inactivas: Un Estudio de Intervención Cuasi-Experimental

Hernández-Jaña, Sam¹; Abarca-Moya, Diego² ; Cid-Pizarro, Ítalo² ; Gallardo-Strelow, José²; González-Pino, Yovanni²; Zavala-Crichton, Juan Pablo ${ }^{3}$; Olivares-Arancibia, Jorge ${ }^{1,4}$; Mahecha-Matsudo, Sandra ${ }^{5,6}$ \& Yáñez-Sepúlveda, Rodrigo ${ }^{7,8}$

HERNÁNDEZ-JAÑA, S.; ABARCA-MOYA, D.; CID-PIZARRO, I.; GALLARDO-STRELOW, J.; GONZÁLEZ-PINO, Y.; ZAVALA-CRICHTON, J. P.; OLIVARES-ARANCIBIA, J.; MAHECHA-MATSUDO, S. \& YÁÑEZ-SEPÚLVEDA, R. Effects of a concurrent training protocol on body composition and phase angle in physically inactive young women: A quasi-experimental intervention study. Int. J. Morphol., 39(6):1600-1608, 2021.

SUMMARY: To determine the effect of a concurrent training program on body composition and phase angle in young women. 38 women (19.26 \pm 1.86 years) participated in the study, and were assigned according to convenience sampling into two groups: 11 into the control group (CG) and 27 into the intervention group (IG). The IG performed a 12-weeks concurrent training protocol. The frequency was five days a week, and the intensity was established in 40-60\% of a repetition maximum to strength exercise, and 40-65\% heart rate reserve to endurance exercise. Body composition and phase angle were evaluated by bioelectrical impedance before and after the intervention. The IG had a decrease in fat mass (pre $=24.66 \pm 5.65 \mathrm{~kg} ;$ post $=20.38 \pm 4.20 \mathrm{~kg}$; Cohen's d = .80; p<0,001 [CI $95 \%=$ $3.34,5.22]$ ), and an increase in muscle mass (pre $=22.75 \pm 3.23 \mathrm{~kg} ;$ post: $23.50 \pm 3.41 \mathrm{~kg}$; Cohen's d $=-0.86 ; \mathrm{p}=\langle 0,001$ [CI $95 \%=-1.09$,$0.40]$ ) and total phase angle (pre $=5.72^{\circ} \pm 0.39$; post: $6.24^{\circ} \pm 0.51$; Cohen's $d=-1.32 ; \mathrm{p}=<0,001$ [CI $\left.95 \%=-0.67,-0.36\right]$ ), whereas the CG had not show significant variations in variables of body composition or total phase angle. The results suggest that a 12 -weeks concurrent training program could modify positively the young women's body composition and phase angle. Hence, it is recommended using similar protocols to change variables related to young women's health.

KEY WORDS: Exercise; Bioelectrical impedance; Young women; Health.

\section{INTRODUCTION}

The 2016-2017 Chilean National Health Survey that evaluated a representative sample of the population aged over 15 years found that $39.8 \%$ of Chilean population was overweight, and $31.2 \%$ was obese. In the case of women, overweight and obesity levels increased concerning previous national survey (Ministerio de Salud, 2017), decreasing the proportion of people with normal weight. This survey provides alarming information about women: $29.1 \%$ smoke, $90 \%$ is sedentary, $36.4 \%$ overweight, $33.7 \%$ obese, and $4.7 \%$ is morbidly obese. Moreover, $27.7 \%$ presents suspected arterial hypertension, $14 \%$ suspected diabetes mellitus, and $2.8 \%$ self-reported of acute myocardial infarction.

Regarding the physical activity (PA), the last National Survey on Physical Activity Behavior and Sport 2018 in population aged 18 years or more, found that $74.2 \%$ of Chilean women are physically inactive (Ministerio del Deporte, 2018). Indeed, a research on Chilean university students found that $88 \%$ of women were physically inactive

\footnotetext{
${ }^{1}$ Grupo IRyS, Escuela de Educación Física. Pontificia Universidad Católica de Valparaíso, Valparaíso, Chile.

${ }^{2}$ Escuela de Educación Física. Pontificia Universidad Católica de Valparaíso, Valparaíso, Chile.

${ }^{3}$ Facultad de Educación y Ciencias Sociales, Universidad Andres Bello, Chile.

${ }^{4}$ Grupo AFySE, Investigación en Actividad Física y Salud Escolar, Escuela de Pedagogía en Educación Física, Facultad de Educación, Universidad de las Américas, Chile.

${ }^{5}$ Unidad Académica, Clínica MEDS, Santiago, Chile.

${ }^{6}$ Post Grado, Facultad de Ciencias, Universidad Mayor, Santiago, Chile

${ }^{7}$ Escuela de Educación. Pedagogía en Educación Física. Universidad Viña del Mar, Viña del Mar, Chile.

${ }^{8}$ Red Iberoamericana de Investigadores en Antropometría Aplicada (RIBA).
} 
HERNÁNDEZ-JAÑA, S.; ABARCA-MOYA, D.; CID-PIZARRO, I.; GALLARDO-STRELOW, J.; GONZÁLEZ-PINO, Y.; ZAVALA-CRICHTON, J. P.; OLIVARES-ARANCIBIA, J.; MAHECHA-MATSUDO, S. \& YÁÑEZ-SEPÚLVEDA, R. Effects of a concurrent training protocol on body composition and phase angle in physically inactive young women: A quasi-experimental intervention study. Int. J. Morphol., 39(6):1600-1608, 2021.

(Rodríguez et al., 2013). In summary, women's group has the highest index of sedentarism and physical inactivity in Chile. In addition, $74.8 \%$ of women have excess weight, which increases the risk in different health problems, such as diabetes mellitus type 2, cardiovascular disease, cancer, asthma, infertility, and an increase of morbidity and mortality (Hruby et al., 2016).

The evidence shows that PA and exercise can reduce body weight, and improve cardiometabolic parameters in people with overweight or obesity (Swift et al., 2018). Furthermore, it has been pointed out that exercise can be prescribed as a therapy for different chronic diseases (Pedersen \& Saltin, 2015). Several studies have found that the increase of cardiorespiratory fitness could decrease the risk of all-cause mortality, coronary heart and cardiovascular diseases, and adiposity and metabolic markers linked to cardiometabolic diseases, as well as, improve expectancy and quality of life (Kodama et al., 2009; Watson \& Baar, 2014; Cristi-Montero et al., 2016). Therefore, choosing the activity or exercise type is an important task to determine the benefits of practice, due to the fact that variables as intensity, time, and frequency are essential to improve health (Hills et al., 2015). In this regard, concurrent-strength and endurance exercise combined-training provides benefits on body composition and biochemical variables associated with health, similar to the benefits obtained from aerobic exercise matching workload (Monteiro et al., 2015). Nevertheless, concurrent training has an additional component due to the resistance exercise, which promotes higher adaptations on muscle morphology when compared with aerobic training (Grgic et al., 2019). Resistance training is important because it is a predictor of mortality in adults (García-Hermoso et al., 2018), which represents a significant contribution to prevention and control of population health. Indeed, concurrent training have shown benefits in young women that performed different exercise protocols (Silva et al., 2012).

According to the best of the authors' knowledge, there is little evidence about concurrent training on phase angle (PhA) (Mundstock et al., 2018). The latter is a health indicator that allows to determine the nutritional or functional impaired status, reflecting health cell and cell membrane integrity. This indicator is provided by bioelectrical impedance and is derived from two components: resistance and reactance of body tissues, being both va- riables dependent mainly on body water and muscle mass respectively (Norman et al., 2012). Women used to have lower values of $\mathrm{PhA}$ compared with male population (BosyWestphal et al., 2006). Consequently, it is important to know what impact of concurrent training is, considering its characteristics and benefits from combining different exercises on health parameters on young women.Thus, the present study aims to determine the effects of a 12-week concurrent training protocol on body composition and phase angle in physically inactive young women. According to this objective, it is hypothesized that concurrent training could modify positively the values of body composition and phase angle.

\section{MATERIAL AND METHOD}

Participants. 43 women were directly invited to this quasiexperimental design study, non-randomized with a quantitative approach. Participants were assigned into two groups according to convenience sampling; however, 5 women were excluded for disease and injury. Thus, 38 women finished the intervention, so they were included in the analysis (Fig. 1): 11 in the control group (CG: aged 20.09 \pm 1.92 ) and 27 in the intervention group (IG: aged $18.93 \pm$ 1.75). The CG was composed of university students of the Faculty of Philosophy and Education of the Pontificia Universidad Católica de Valparaíso, whereas the IG consisted of conscripts of a military unit. Participants were physically inactive $(<150$ or $<75$ minutes of moderate or vigorous

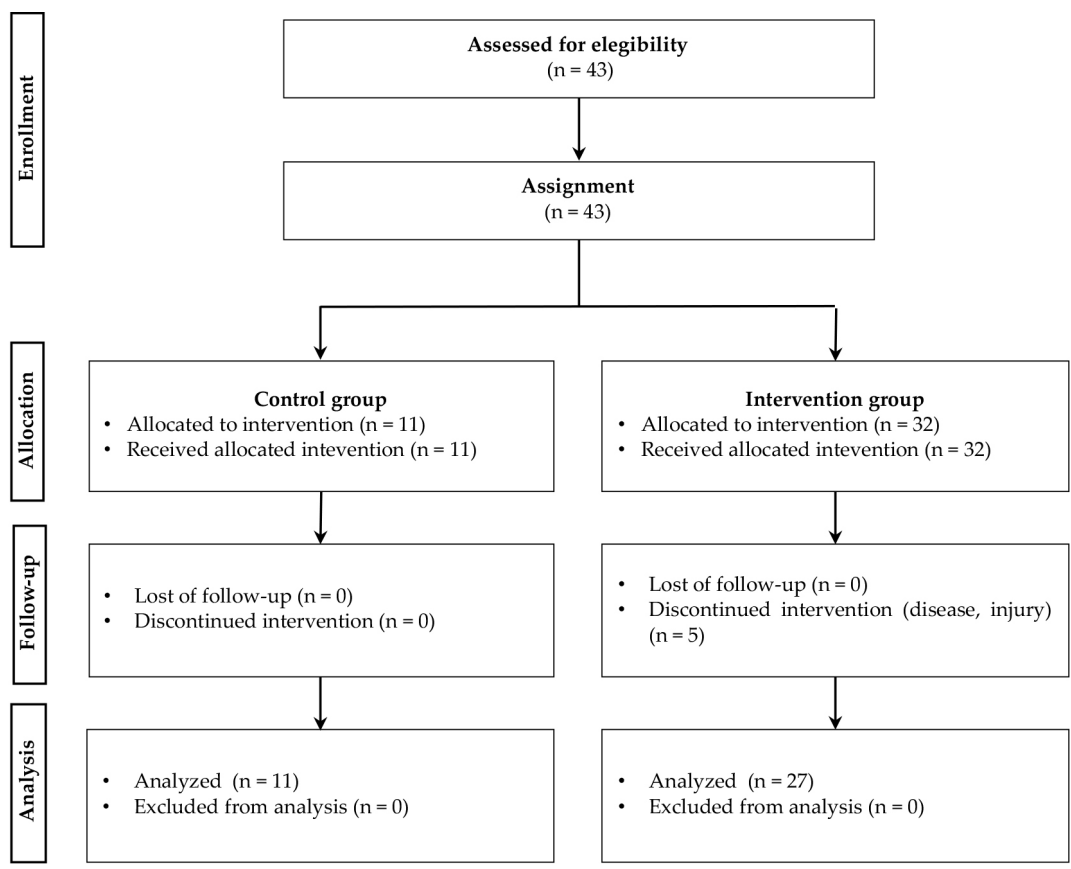

Fig. 1. Diagram chart of the participants of study. 
HERNÁNDEZ-JAÑA, S.; ABARCA-MOYA, D.; CID-PIZARRO, I.; GALLARDO-STRELOW, J.; GONZÁLEZ-PINO, Y.; ZAVALA-CRICHTON, J. P.; OLIVARES-ARANCIBIA, J.; MAHECHA-MATSUDO, S. \& YÁÑEZ-SEPÚLVEDA, R. Effects of a concurrent training protocol on body composition and phase angle in physically inactive young women: A quasi-experimental intervention study. Int. J. Morphol., 39(6):1600-1608, 2021.

physical activity per week, respectively), and had a regular menstrual cycle (28 to 32 days). All participants were receiving contraceptive oral treatment, except anyone taking medication for a chronic disease. Diet was adjusted by a nutritionist in the IG according to daily requirements, whereas the CG only received counselling nutrition.

Inclusion criteria were women aged between 18 to 25 , voluntary participation, or failure to comply with weekly physical activity recommendations of the World Health Organization (150 minutes of moderate physical activity or 75 minutes of vigorous physical activity). Exclusion criteria were one or more chronic diseases, pregnancy, tobacco consumption, pharmaceutical consumption, or using a metallic prosthesis or pacemaker during bioelectrical impedance.

Anthropometry. Participants were evaluated before and after the intervention, considering a previous period of 48 hours without moderate-to-vigorous physical activity. Weight was evaluated with a Tanita®digital scale (Model HD-313, Tokyo, Japan) with a precision of $100 \mathrm{~g}$, and height was obtained with a CAM $®$ stadiometer (Buenos Aires, Argentina) with a precision of $1 \mathrm{~mm}$. Body mass index (BMI) was calculated as weight $(\mathrm{kg})$ divided by square of height $(\mathrm{m})$ $\left(\mathrm{kg} / \mathrm{m}^{2}\right)$. Weight was evaluated in the early morning while fasting, and after urination. Height was measured through standing balance. The participants put their backs against the stadiometer, and their heels together. The head was placed in Frankfort plane while the evaluator was pulling upward. Finally, the assistant put the square firmly on the participant's head (vertex) to register the values in meters. The measures were carried out according to the guidelines of The International Society for the Advancement of Kinanthropometry (Stewart et al., 2011).

Body composition. Body composition was evaluated through an InBodyS100 octopolar bioelectrical impedance and multi-frequency analyzer (Seoul, Korea) of 6 frequencies $(1 \mathrm{kHz}, 5 \mathrm{kHz}, 50 \mathrm{kHz}, 250 \mathrm{kHz}, 500 \mathrm{kHz}, 1 \mathrm{MHz})$. This instrument provides values of fat-free mass, fat mass, waist circumferences, arm perimeter, body cell mass, muscle mass, body fat percentage, visceral fat area, corrected arm perimeter, bone mineral content, lean body mass, PhA, reactance, impedance, and body water. The procedure of bioelectrical impedance followed the protocol suggested by (Rodríguez \& Almagià (2016). Participants were evaluated while lying down, being barefoot, and without having

Table I. Progression of the intervention program.

\begin{tabular}{lcccc}
\hline \multicolumn{1}{c}{ Exercise } & Week 1-3 & Week 4-6 & Week 7-9 & Week 10-12 \\
\hline Resistance (\%RM) & $40-45$ & $45-50$ & $50-55$ & $55-60$ \\
Aerobic (\%HRR) & $40-45$ & $45-50$ & $50-55$ & $55-65$ \\
\hline
\end{tabular}

RM: repetition maximum; HRR: heart rate reserve. metallic elements that could disrupt the information or put the participants integrity at risk.

Intervention program. Before start intervention, participants had a preparation week in which general considerations and research scope were detailed. The CG had only a counseling nutrition, whereas the IG received a talk with the intervention protocol explanation. Moreover, this group had similar rest, eating and physical activity routines because they were members of a military unit.

The program was led by a physical education teacher with a university degree, performing all sessions at $8.00 \mathrm{am}$. The resistance training was done 5 times per week, using multi-articular and mono-articular exercises. The duration of every session was 60 minutes, and the intensity was calculated through one-repetition maximum for the resistance exercise, with a range of repetition maximum of work between $40 \%$ and $60 \%$. The program and progression were designed according to the model of progression provided by The American College of Sports Medicine (2009) with the progress of the $5 \%$ per cycle. Each exercise was performed in a 3 series of 10 to 20 repetitions with rest intervals of 1-2 minutes between series, and 3 minutes after each exercise. The execution velocity was 1-2 seconds concentric and 1-2 seconds eccentric; every session consisted of 6 to 8 exercises to train a specific muscle group. Monday: lower limb; Tuesday: pectoral and biceps muscles; Wednesday: back and triceps muscles; Thursday: lower limb; Friday: pectoral, biceps, back and triceps muscles. The aerobic training was jogging, with a frequency of 5 times per week, and a duration of 30 minutes per session at intensity between $40 \%$ and 65 $\%$ of heart rate reserve, calculated using the prediction equations proposed by Tanaka for maximum heart rate $(H R \max =208-07 \mathrm{x}$ age $)$ and Karvonen's for the heart rate of training ([(HRmax - HRrest) $x \%$ training $]+$ FCrest $)$ (Karvonen, 1957; Tanaka et al., 2001). Table I shows the intensity progression of the program for intervention group. Every training had the same sequence: the resistance exercise was performed first and then the aerobic training. All sessions were performed on stable surfaces and outdoors.

Ethical considerations. All participants voluntarily signed an informed consent form previous to the intervention, which detailed the objectives and procedures of the research. The present study was conducted according to the current Declaration of Helsinki to research with human beings (World Medical Association, 2013). 
HERNÁNDEZ-JAÑA, S.; ABARCA-MOYA, D.; CID-PIZARRO, I.; GALLARDO-STRELOW, J.; GONZÁLEZ-PINO, Y.; ZAVALA-CRICHTON, J. P.; OLIVARES-ARANCIBIA, J.; MAHECHA-MATSUDO, S. \& YÁÑEZ-SEPÚLVEDA, R. Effects of a concurrent training protocol on body composition and phase angle in physically inactive young women: A quasi-experimental intervention study. Int. J. Morphol., 39(6):1600-1608, 2021.

Statistical analysis. Descriptive variables were shown as mean and standard deviation. Shapiro-Wilk test was used to determine the normality of the data. A t-Student and Mann Whitney U tests were used to compare independent samples, and the t-Student and Wilcoxon tests were performed to determine differences between paired samples. Size effect was determined by Cohen's d, which was interpreted as no effect $(<0.2)$, small $(0.2$ to $<0.5)$, medium $(0.5$ to $<0.8)$, and large $(\geq 0.8)$ (Cohen, 1992). The significance level was set at $\mathrm{p}<0.05$. The analysis was performed using IBM SPSS $\AA$ Statistics version 25 for Mac (IBM, Chicago, Illinois, USA).

\section{RESULTS}

Table II shows a comparative analysis of baseline characteristics before the intervention. Statistical differences were found in terms of age $(\mathrm{p}=0.006 *$ [CI $95 \%=$ $0.00,2.00])$, BMI $(\mathrm{p}=0.017$ [CI $95 \%=-4.78,0.50])$, fat mass $(\mathrm{p}=0.022[-9.55,-0.80])$, and reactance $(\mathrm{p}=0.037$ [CI $95 \%=0.12,3.64)$.

Table III presents body composition values by group before and after the intervention. Moreover, the delta of both, CG and IG, were compared. Significant differences were found in almost all analyzed variables of the IG, decreasing weight by a $4.9 \%$ (Cohen's $d=1.23 ; \mathrm{p}<0.001$ [CI $95 \%=$ $2.22,4.33]$ ) and fat mass by a $4.7 \%$ fat mass (Cohen's $\mathrm{d}=$ $2.20 ; \mathrm{p}<0.001$ [CI $95 \%=3.84,5.52]$ ); fat-free mass increased by a $2.7 \%$ (Cohen's $d=-0.83 ; \mathrm{p}<0.001$ [CI $95 \%$ $=-1.64,-0.58]$ ) and muscle mass by a $3.3 \%$ (Cohen's $\mathrm{d}=-$ $0.86 ; \mathrm{p}<0.001$ [CI $95 \%=-1.09,-0.40]$, being all differences statistically significant compared to the delta of CG. This latter group had a single significant decrease in body cell mass (Cohen's $\mathrm{d}=0.73 ; \mathrm{p}=0.37$ [CI $95 \%=0.01,0.13]$ ) and an increase in right arm lean mass (Cohen's $d=-0.70 ; p$ $=0.043[$ CI $95 \%=-0.11,-0.00])$.
Table IV shows PhA, reactance, impedance, and body water values by group before and after the intervention. Besides, the delta of both, CG and IG, were compared. After the intervention, significant increases were observed in $\mathrm{PhA}$ and body water in all body segments of the IG, whereas the $\mathrm{CG}$ just presented significant increases in right arm $\mathrm{PhA}$ (Cohen's $\mathrm{d}=-1.34 ; \mathrm{p}=0.001$ [CI $95 \%=-0.50,0.17]$ ) and decreases in trunk PhA (Cohen's d = 0.98; $\mathrm{p}=0.009$ [CI 95 $\%=0.31,1.67])$. Regarding reactance, the IG had significant increases in all body parts, except the right arm (Cohen's d $=-0.16 ; \mathrm{p}=0.407$ [CI $95 \%=-2.01,0.84]$ ), whereas the CG did not have any significant variations in this parameter. The impedance of the IG had non-significant decreases in all body parts, whereas the CG had a single significant decrease in the right arm (Cohen's d; p $=0.005$ [CI $95 \%=$ $4.77,16.06])$. Finally, all variables related to body water significantly increased in the IG, whereas CG did not have any significant variations.

\section{DISCUSSION}

The present study aimed to determine the effects of a 12-week concurrent training protocol on body composition and $\mathrm{PhA}$ in physically inactive young women. The main findings were, on the one hand, a statistically significant increase of muscle mass, fat-free mass, $\mathrm{PhA}$, and a decrease in fat mass in the IG; on the other hand, the CG decreased in all variables above mentioned but any statistically significant. These results may be helpful due mainly to scarce evidence in the type of exercise and $\mathrm{PhA}$ modifications in this population.

Body composition. The concurrent training has resistance and aerobic components, which could represent a key point in the significant modifications on body composition of the IG, because it combines two types of training widely

Table II. Mean and standard deviation of baseline characteristics of the body composition and bioelectrical impedance.

\begin{tabular}{|c|c|c|c|c|c|c|c|}
\hline \multirow{2}{*}{ Variables } & \multicolumn{2}{|c|}{ All $(n=38)$} & \multicolumn{2}{|c|}{$\mathrm{CG}(\mathrm{n}=11)$} & \multicolumn{2}{|c|}{ IG $(n=27)$} & \multirow{2}{*}{$\begin{array}{c}\text { CG x IG } \\
p \text {-value (CI } 95 \%)\end{array}$} \\
\hline & Mean & $\pm \mathrm{SD}$ & Mean & $\pm \mathrm{SD}$ & Mean & $\pm \mathrm{SD}$ & \\
\hline Age (years) & 19.26 & \pm 1.86 & 20.09 & \pm 1.92 & 18.93 & \pm 1.75 & $* 0.006(0.00,2.00)$ \\
\hline W eight (kg) & 65.01 & \pm 9.41 & 61.45 & \pm 9.88 & 66.46 & \pm 8.99 & $0.139(-11.72,1.70)$ \\
\hline Height (m) & 1.62 & \pm 0.07 & 1.63 & \pm 0.06 & 1.61 & \pm 0.07 & ${ }^{\dagger} 0.301(-0.02,0.07)$ \\
\hline BMI $\left(\mathrm{kg} / \mathrm{m}^{2}\right)$ & 24.87 & \pm 3.15 & 22.99 & \pm 2.68 & 25.63 & \pm 3.05 & $* 0.017(-4.78,0.50)$ \\
\hline Muscle mass (kg) & 22.78 & \pm 3.10 & 22.86 & \pm 2.93 & 22.75 & \pm 3.23 & $0.919(-2.17,2.40)$ \\
\hline $\mathrm{F}$ at free mass $(\mathrm{kg})$ & 41.86 & \pm 5.20 & 41.97 & \pm 4.84 & 41.81 & \pm 5.42 & $0.931(-3.66,3.99)$ \\
\hline $\mathrm{F}$ at mass $(\mathrm{kg})$ & 23.16 & \pm 6.41 & 19.48 & \pm 6.93 & 24.66 & \pm 5.65 & $* 0.022(-9.55,-0.80)$ \\
\hline $\mathrm{PhA}\left({ }^{\circ}\right)$ total & 5.75 & \pm 0.40 & 5.81 & \pm 0.43 & 5.72 & \pm 0.39 & $0.535(-0.20,0.39)$ \\
\hline $\mathrm{Xc}(\Omega)$ total & 26.75 & \pm 2.55 & 28.09 & \pm 1.80 & 26.21 & \pm 2.63 & $* 0.037(0.12,3.64)$ \\
\hline $\mathrm{Z}(\Omega)$ total & 273.39 & \pm 25.77 & 283.42 & \pm 15.45 & 273.46 & \pm 29.53 & $0.184(-4.99,24.90)$ \\
\hline
\end{tabular}

*Statistical difference; †U Mann-Whitney test; CG: control group; IG: intervention group; CI: confidence interval; PhA: phase angle; Xc: reactance; $\mathrm{Z}$ : impedance; $\Omega$ : Ohmios. 


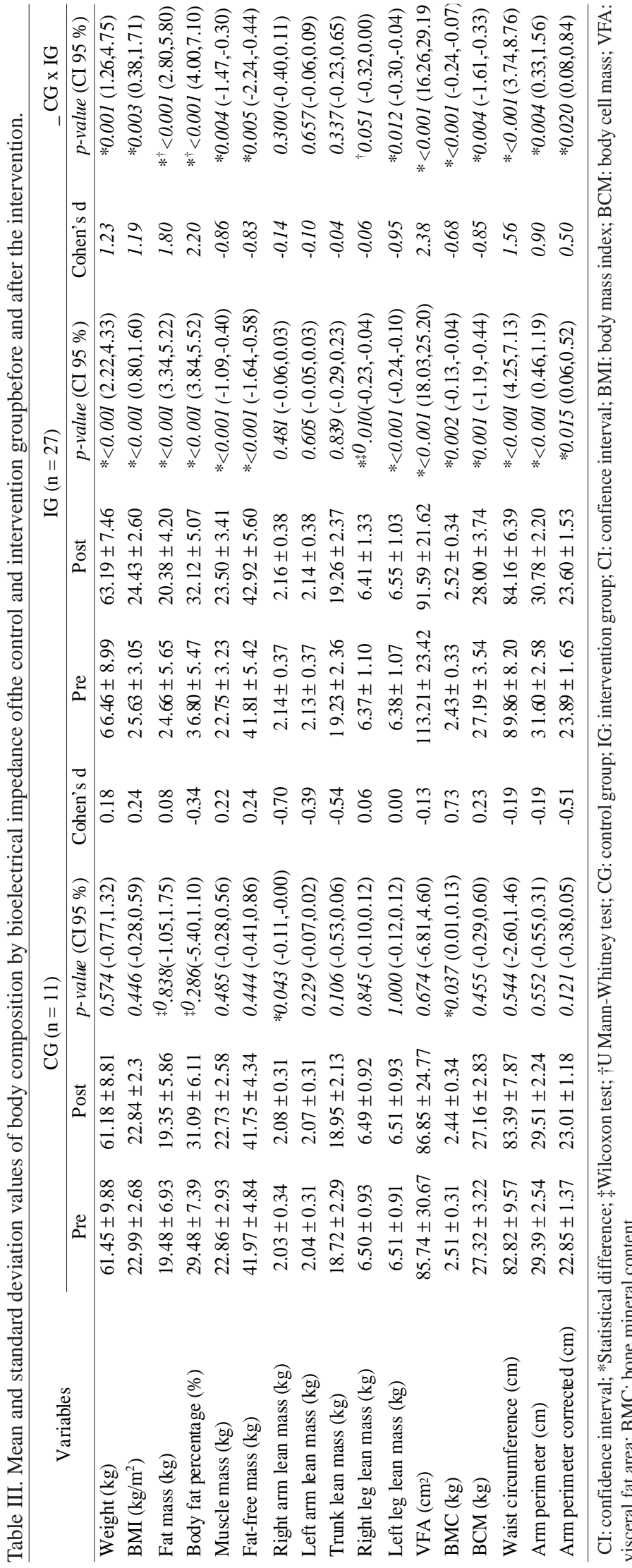

documented in the health field (Garber et al., 2011; Westcott, 2012; Pedersen \& Saltin). A 10-week resistance training research on women to determine the changes on body composition without inducing an inflammatory response found a decrease in fat mass and an increase in lean mass without eliciting an inflammatory response (Ferreira et al., 2010). Furthermore, a study about resistance training and body composition found that body fat percentage was lower when women exercised more; however, these benefits could be reduced for menopause (Burrup et al., 2018). Therefore, age could be a key point to intervene and modify body composition variables in women.

In relation to aerobic training, a piece of research compared 3 types of training on body composition in men and women, dividing exercise according to intensity. The main findings were that the more intense the aerobic exercise was, the higher the benefits were. What's more, even lower intensity exercise without tracking diet improved participants' body composition (Chiu et al., 2017). Another study found enhancements in light-to-moderate aerobic exercise performed by women with overweight and obesity, compared with a control group. However, moderate intensity exercise had a higher impact on weight, BMI, body fat percentage, fat mass, lean mass and waist-to-hip ratio (Marandi et al., 2013). While results are similar with our study but a fewer number of training per week, the latter research had participants with higher values in fat mass, which could explain the significant reduction of body composition components due to differences are most significant at the beginning of the intervention or when participants are more deconditioned.

Each component of the concurrent training proposes modifications in body composition independently. However, interventions have been carried out to determine the effects of resistance and simultaneous aerobic training on body variables. For instance, a study investigated the effects of two types of training in healthy obese women; high-impact aerobics and low-impact aerobics combined with strength training. High-impact aerobics enhanced loss weight and fat mass, whereas low-impact aerobics combined with strength training improved fat-free mass, aerobic fitness, and muscle strength. Furthermore, both exercise methods decreased weight, fat mass, and cardiovascular disease risks (Said et al., 2017). Another study that compared the effects of the endurance training and endurance strength training found that both types of training provided similar benefits to weight, fat mass and lean mass (Skrypnik et al., 2015). Finally, a piece 
HERNÁNDEZ-JAÑA, S.; ABARCA-MOYA, D.; CID-PIZARRO, I.; GALLARDO-STRELOW, J.; GONZÁLEZ-PINO, Y.; ZAVALA-CRICHTON, J. P.; OLIVARES-ARANCIBIA, J.; MAHECHA-MATSUDO, S. \& YÁÑEZ-SEPÚLVEDA, R. Effects of a concurrent training protocol on body composition and phase angle in physically inactive young women: A quasi-experimental intervention study. Int. J. Morphol., 39(6):1600-1608, 2021.

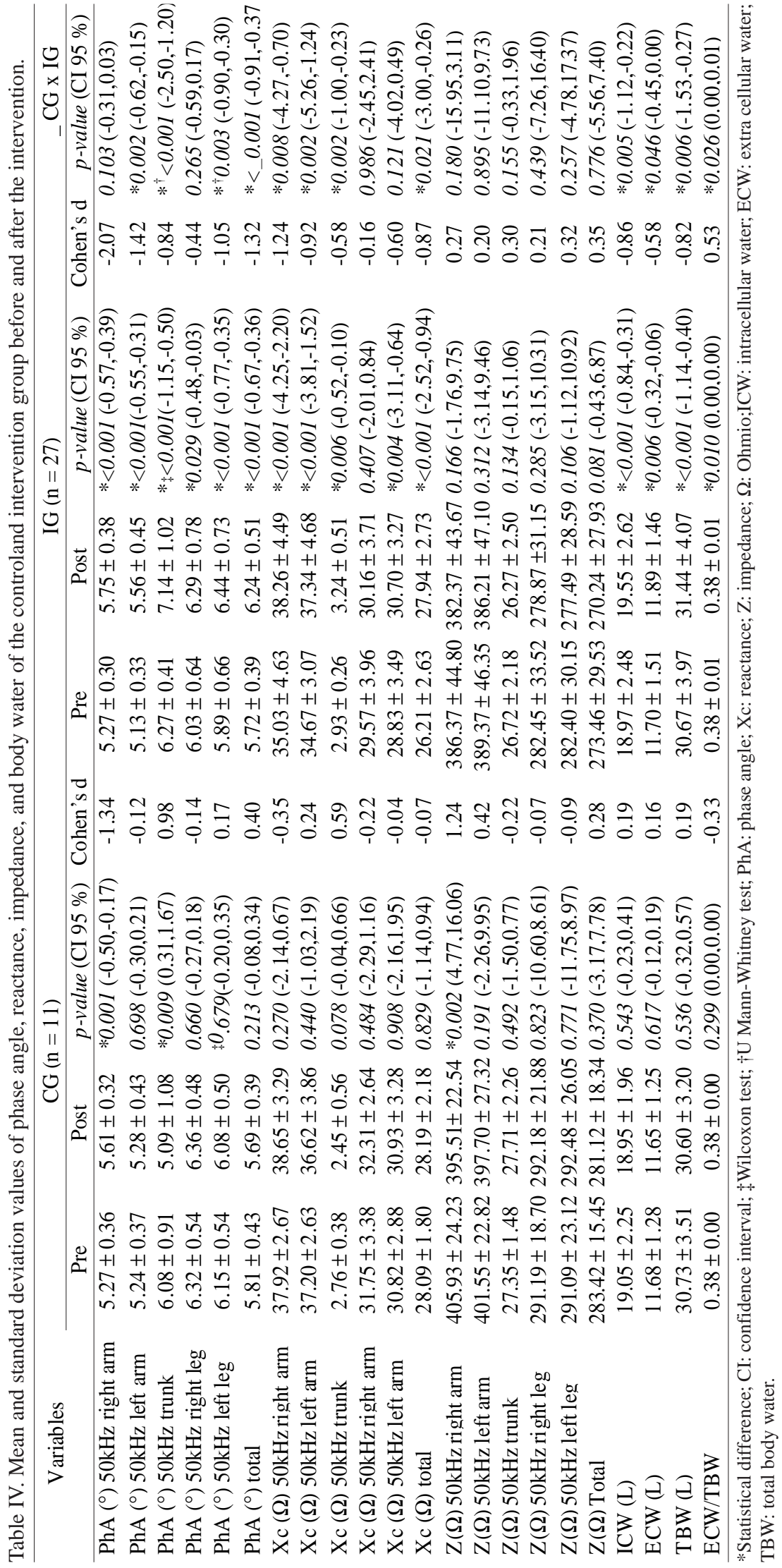

of research on obese adolescents compared the effect of aerobic training and concurrent training, finding that both types of exercise provided similar outcomes on weight fat-free mass, and fat mass (Monteiro et al., 2015). These findings are consistent with the results of the present study, in which significant changes in almost all body composition variables were observed in the IG. This could be explained because this group had both type of exercise 5 days per week, and the variation of body composition has been specifically associated with type of aerobic and strength training to decrease fat mass or increase fat free mass (Willis et al., 2012).

Phase angle. The intervention protocol results on $\mathrm{PhA}$ indicate a significant increase on all body segments, which could be explained not only by fat mass decrease, but also by lean mass increase (Rodríguez-Rodríguez et al., 2016). A systematic review and meta-analysis about the PA and $\mathrm{PhA}$ found a positive effect between variables, being the $\mathrm{PhA}$ a useful marker to determine the prognosis of the cell health (Mundstock et al.). These results represent a fundamental precedent in clinical practice, treatment, and prevention through PA in healthy and subject at risk of chronic diseases, since the yallow to guide objectives of training according to the group's characteristics, understanding the impact and benefits linked to the cell health indicators that might be achieved through PA.

Several studies have evaluated the response of the $\mathrm{PhA}$ through different types and intensity exercises. One of them analyzed the $\mathrm{PhA}$ through resistance training, finding an increase of the $\mathrm{PhA}$ independently of sex, which could be attributed to the rising of the intracellular water (Ribeiro et al., 2017a). This increase is caused mainly by cellular hydration, which reduces the resistive components of the body tissues; however, the results of this study 
HERNÁNDEZ-JAÑA, S.; ABARCA-MOYA, D.; CID-PIZARRO, I.; GALLARDO-STRELOW, J.; GONZÁLEZ-PINO, Y.; ZAVALA-CRICHTON, J. P.; OLIVARES-ARANCIBIA, J.; MAHECHA-MATSUDO, S. \& YÁÑEZ-SEPÚLVEDA, R. Effects of a concurrent training protocol on body composition and phase angle in physically inactive young women: A quasi-experimental intervention study. Int. J. Morphol., 39(6):1600-1608, 2021.

show not only a decrease in the resistance, but also an increase in the reactance. It has been documented previously how exercise modifies body water, decreasing the resistance and therefore the $\mathrm{PhA}$ (Ribeiro et al., 2017b). Nevertheless, the increase of the resistance might be due to the aerobic exercise performed for the IG and the increase of the body cell mass, because it has been proven that there is an association between this increase and exercise performance (Pigtowska et al., 2016). Whereas the hypothesis lacks robust evidence, the scarcity of studies that have determined how the aerobic exercise affects the PhA justifies the need to study further in this field (Mundstock et al.).

Regarding endurance exercise on $\mathrm{PhA}$, a pilot study on obese women that compared the effects of an endurance training program found that endurance training added to a whole-body vibration training had better results on PhA. Nonetheless, the endurance exercise alone decreased on this indicator (Wilms et al., 2012). Whereas the sample was small, and the follow-uplasted just 6 weeks, the current evidence lacks studies with these characteristics. Thus, it is important to add background to determine the relation dose-response of these exercise types on bioelectrical parameters related to health. Lastly, only a single paper has proven the outcomes of the concurrent training on PhA; nevertheless, the participants were older women with chronic obstructive pulmonary disease. That is why this study is not suitable for our research analysis (Jungblut et al., 2009; Mundstock et al.).

The results of total PhA of the IG after the intervention are concordant with a systematic review and meta-analysis carried out in more than 250,000 subjects which found that women aged 19 to 28 years had a mean value of 6.1 regarding $\mathrm{PhA}$, which is lower than the one presented in our results (Mattiello et al., 2019). Furthermore, the values obtained in our study were higher than the ones obtained from a study carried out in more than 180,000 German women, which established cut-off points by, age, and BMI; this provided reference values to women aged 20 to 29 years with normal weight and a PhA of 5.98, and women with the same age but with overweight, and a PhA of 6.10 (Bosy-Westphal et al.).

On the other hand, a review that established cut-off points in different populations, defined a $\mathrm{PhA}$ value of 7.04 in American women aged 18 to19 years, and a value of 6.98 in women aged 20 to 29 years (Llames et al., 2013), being higher than the CG and the IG of the present study.These differences could be due to the variability of the impedance method, which has been mentioned in the previous research. This highlights the importance of standardizing the protocol to the population in order to obtain more accurate outcomes (González-Correa \& Caicedo-Eraso, 2012).

\section{CONCLUSIONS}

Concurrent training seems to be an appropriate alternative to modify body composition and $\mathrm{PhA}$ in young women. This is due to the fact that the stimulus caused by endurance exercise and resistance exercise decreased the fat mass and increased the lean mass. Whereas the results could be predicted considering type and volume of exercise, the reduction of the resistance and rising of the reactance that positively modified the PhA suggest that results might be useful to choose the approach and exercise prescription in a population that requires improving their health condition. Lastly, it has been confirmed that concurrent training provides significant changes in all body segments; thus, it is suggested the use of the concurrent training protocol of the present study or a similar one in order to enhance body composition and bioelectrical parameters linked to health.

Strength and limitations. Body composition was not evaluated by the gold standard which could increase the variability of the outcomes. Moreover, participants were not chosen and allocated randomly due to both groups belonged to different contexts (university students [CG] and members of a military units [IG]), which represents a selection bias towards the outcomes. In the case of the CG, certain aspects were not covered, which could have interfered with the results. In this regard, the participants' university lifestyle is characterized by individual modifications in rest, eating, and physical activity. Therefore, this could represent another bias towards the outcomes by not controlling these variables. On the other hand, one of the strengths of our study has relation to the fact that the IG constantly controlled all variables, because this group consisted of members of The Chilean Air Force. This means that all participants had similar rest, eating and physical activity routines. However, overweight and higher values of fat mass at the beginning of intervention could explain the significant decrease in these parameters regarding the CG. Finally, another strength of our study according to the best of the authors' knowledge, is that this research is ground-breaking when it comes to evaluating how concurrent training affects the PhA on healthy young women without illnesses, providing guidelines that could address future research on this field.

Future implications. The use of bioelectrical impedance and, particularly, application of the $\mathrm{PhA}$ on the clinical field has produced great results for the scientific community. Consequently, the application of this method in a preventive way could have favorable results for the population. It seems reasonable enough to conduct studies that allow to know the outcomes of different protocols of training on PhA in different populations, age groups, and health conditions. 
HERNÁNDEZ-JAÑA, S.; ABARCA-MOYA, D.; CIDPIZARRO, I.; GALLARDO-STRELOW, J.; GONZÁLEZPINO, Y.; ZAVALA-CRICHTON, J. P.; OLIVARESARANCIBIA, J.; MAHECHA-MATSUDO, S. \& YÁÑEZSEPÚLVEDA, R. Efectos de un protocolo de entrenamiento concurrente sobre la composición corporal y el ángulo de fase en mujeres jóvenes físicamente inactivas: un estudio de intervención cuasi-experimental. Int. J. Morphol., 39(6):1600-1608, 2021.

RESUMEN: El objetivo fue determinar el efecto de un programa de entrenamiento concurrente sobre la composición corporal y el ángulo de fase en mujeres jóvenes. 38 mujeres (19.26 1.86 años) participaron en el estudio, y fueron asignadas de acuerdo a un muestreo de conveniencia en dos grupos: 11 en el grupo control (CG ) y 27 en el grupo de intervención (GI). El IG realizó un protocolo de entrenamiento concurrente de 12 semanas. La frecuencia fue de cinco días a la semana y la intensidad se estableció en 40-60 \% una repetición máxima para el ejercicio de fuerza y $40-65 \%$ de frecuencia cardíaca de reserva para ejercicio de resistencia. La composición corporal y el ángulo de fase se evaluaron mediante impedancia bioeléctrica antes y después de la intervención. El IG tuvo una disminución en la masa grasa $($ pre $=24.66 \pm 5.65 \mathrm{~kg} ;$ post $=20.38 \pm 4.20 \mathrm{~kg} ; \mathrm{d}$ de Cohen $=.80$; $\mathrm{p}<0,001$ [IC $95 \%=3.34,5.22]$ ), y un aumento en la masa muscular (pre $=22,75 \pm 3,23 \mathrm{~kg}$; post: $23,50 \pm 3,41 \mathrm{~kg}$; $\mathrm{d}$ de Cohen $=$ $-0,86 ; \mathrm{p}=<0,001[$ [IC $95 \%=-1,09,-0,40])$ y ángulo de fase total (pre $=5,72^{\circ} \pm 0,39 ;$ post: $6,24^{\circ} \pm 0,51 ; \mathrm{d}$ de Cohen $=-1,32 ; \mathrm{p}=$ $<0,001$ [IC $95 \%=-0,67,-0,36]$ ), mientras que el GC no mostró variaciones significativas en las variables de composición corporal o ángulo de fase total. Los resultados sugieren que un programa de entrenamiento concurrente de 12 semanas podría modificar positivamente la composición corporal y el ángulo de fase de mujeres jóvenes. Por lo tanto, se recomienda utilizar protocolos similares para mofificar variables relacionadas con la salud de mujeres jóvenes.

PALABRAS ClAVE: Ejercicio; Impedancia bioeléctrica; Mujer joven; Salud.

\section{REFERENCES}

American College of Sports Medicine. Progression models in resistance training for healthy adults. Med. Sci. Sports Exerc.; 41(3):687-708, 2009.

Bosy-Westphal, A.; Danielzik, S.; Dörhöfer, R. P.; Later, W.; Wiese, S. \& Müller, M. J. Phase angle from bioelectrical impedance analysis: population reference values by age, sex, and body mass index. $J$. Parenter. Enter. Nutr, 30(4):309-16, 2006.

Burrup, R.; Tucker, L. A.; LE Cheminant, J. D. \& Bailey, B. W. Strength training and body composition in middle-age women. J. Sports Med. Phys. Fitness, 58(1-2):82-91, 2018.

Chiu, C.-H.; Ko, M.-C.; Wu, L.-S.; Yeh, D.-P.; Kan, N.-W.; Lee, P.-F.; Hsieh, J.-W.; Tseng, C.-Y. \& Ho, C.-C. Benefits of different intensity of aerobic exercise in modulating body composition among obese young adults: A pilot randomized controlled trial. Health Qual. Life Outcomes, 15(1):168, 2017.

Cohen, J. A power primer. Psychol. Bull., 112(1):155-9, 1992.
Cristi-Montero, C.; Ramírez-Campillo, R.; Alvarez, C.; Méndez, A. G.; Martínez, M. A.; Martínez, X. D.; Leiva, A. M.; Salas, C.; Gutiérrez, M.; Sanzana-Inzunza, R.; et al. Fitness cardiorrespiratorio se asocia a una mejora en marcadores metabólicos en adultos chilenos. Rev. Med. Chile, 144(8):980-9, 2016.

Ferreira, F. C.; de Medeiros, A. I.; Nicioli, C.; Nunes, J. E. D.; Shiguemoto, G. E.; Prestes, J.; Verzola, R. M. M.; Baldissera, V. \& de Andrade Perez, S. E. Circuit resistance training in sedentary women: Body composition and serum cytokine levels. Appl. Physiol. Nutr. Metab., 35(2):163-71, 2010.

Garber, C. E.; Blissmer, B.; Deschenes, M. R.; Franklin, B. A.; Lamonte, M. J.; Lee, I.-M.; Nieman, D. C.; Swain, D. P. \& American College of Sports Medicine. American College of Sports Medicine position stand. Quantity and quality of exercise for developing and maintaining cardiorespiratory, musculoskeletal, and neuromotor fitness in apparently healthy adults: Guidance for prescribing exercise. Med. Sci. Sports Exerc., 43(7):1334-59, 2011.

García-Hermoso, A.; Cavero-Redondo, I.; Ramírez-Vélez, R.; Ruiz, J. R.; Ortega, F. B.; Lee, D.-C. \& Martínez-Vizcaíno, V. Muscular strength as a predictor of all-cause mortality in an apparently healthy population: a systematic review and meta-analysis of data from approximately 2 million men and women. Arch. Phys. Med. Rehabil., 99(10):2100-13.e5, 2018.

González-Correa, C. H. \& Caicedo-Eraso, J. C. Bioelectrical impedance analysis (BIA): A proposal for standardization of the classical method in adults. J. Phys. Conf. Ser., 407:12018, 2012.

Grgic, J.; Mcllvenna, L. C.; Fyfe, J. J.; Sabol, F.; Bishop, D. J.; Schoenfeld, B. J. \& Pedisic, Z. Does aerobic training promote the same skeletal muscle hypertrophy as resistance training? A systematic review and meta-analysis. Sport. Med., 49(2):233-54, 2019.

Hills, A. P.; Street, S. J. \& Byrne, N. M. Physical activity and health: "what is old is new again." Adv. Food Nutr. Res., 75:77-95, 2015.

Hruby, A.; Manson, J. E.; Qi, L.; Malik, V. S.; Rimm, E. B.; Sun, Q.; Willett, W. C. \& Hu, F. B. Determinants and consequences of obesity. Am. J. Public Health, 106(9):1656-62, 2016.

Jungblut, S. A.; Frickmann, H.; Zimmermann, B.; Müller, U. \& Bargon, J. Die Auswirkungen von Sport auf die Körperzusammensetzung von COPD-Patienten TT - The Effects of Physical Training on the Body Composition of Patients with COPD. Pneumologie, 63(7):374-9, 2009.

Karvonen, M. J. The effects of training on heart rate: A longitudinal study. Ann. Med. Exp. Biol. Fenn., 35:307-15, 1957.

Kodama, S.; Saito, K.; Tanaka, S.; Maki, M.; Yachi, Y.; Asumi, M.; Sugawara, A.; Totsuka, K.; Shimano, H.; Ohashi, Y.; et al. Cardiorespiratory fitness as a quantitative predictor of all-cause mortality and cardiovascular events in healthy men and women: a metaanalysis. JAMA, 301(19):2024-35, 2009.

Llames, L.; Baldomero, V.; Iglesias, M. L. \& Rodota, L. P. Valores del ángulo de fase por bioimpedancia eléctrica; Estado nutricional y valor pronóstico. Nutr. Hosp., 28(2):286-95, 2013.

Marandi, S. M.; Abadi, N. G. B.; Esfarjani, F.; Mojtahedi, H. \& Ghasemi, G. Effects of intensity of aerobics on body composition and blood lipid profile in obese/overweight females. Int. J. Prev. Med., 4(Suppl. 1):S11825, 2013.

Mattiello, R.; Amaral, M. A.; Mundstock, E. \& Ziegelmann, P. K. Reference values for the phase angle of the electrical bioimpedance: Systematic review and meta-analysis involving more than 250,000 subjects. Clin. Nutr., 39(5):1411-7, 2019.

Ministerio de Salud. Encuesta Nacional de Salud 2016-2017. Primeros Resultados. Santiago de Chile, Gobierno de Chile, 2017.

Ministerio del Deporte. Encuesta Nacional de Hábitos de Actividad Física y Deporte 2018 en Población de 18 años y más. Santiago de Chile, Gobierno de Chile, 2018.

Monteiro, P. A.; Chen, K. Y.; Lira, F. S.; Saraiva, B. T. C.; Antunes, B. M. M.; Campos, E. Z. \& Freitas, I. F. Concurrent and aerobic exercise training promote similar benefits in body composition and metabolic profiles in obese adolescents. Lipids Health Dis., 14(1):1-9, 2015. 

intervention study. Int. J. Morphol., 39(6):1600-1608, 2021.

Mundstock, E.; Amaral, M. A.; Baptista, R. R.; Sarria, E. E.; dos Santos, R. R. G.; Filho, A. D.; Rodrigues, C. A. S.; Forte, G. C.; Castro, L.; Padoin, A. V.; et al. Association between phase angle from bioelectrical impedance analysis and level of physical activity: Systematic review and meta-analysis. Clin. Nutr., 38(4):1504-10, 2018.

Norman, K.; Stobäus, N.; Pirlich, M. \& Bosy-Westphal, A. Bioelectrical phase angle and impedance vector analysis - Clinical relevance and applicability of impedance parameters. Clin. Nutr., 31(6):854-61, 2012.

Pedersen, B. K. \& Saltin, B. Exercise as medicine-evidence for prescribing exercise as therapy in 26 different chronic diseases. Scand. J. Med. Sci. Sports, 25(S3):1-72, 2015.

Pig?owska, M.; Kostka, T.; Drygas, W.; Jegier, A.; Leszczyn’́ska, J.; BillBielecka, M. \& Kwas'niewska, M. Body composition, nutritional status, and endothelial function in physically active men without metabolic syndrome - a 25 year cohort study. Lipids Health Dis., 15(1):84, 2016.

Ribeiro, A. S.; Avelar, A.; dos Santos, L.; Silva, A. M.; Gobbo, L. A.; Schoenfeld, B. J.; Sardinha, L. B. \& Cyrino, E. S. Hypertrophy-type resistance training improves phase angle in young adult men and women. Int. J. Sports Med., 38(01):35-40, 2017a.

Ribeiro, A. S.; Schoenfeld, B. J.; Souza, M. F.; Tomeleri, C. M.; Silva, A. M.; Teixeira, D. C.; Sardinha, L. B. \& Cyrino, E. S. Resistance training prescription with different load-management methods improves phase angle in older women. Eur. J. Sport Sci., 17(7):913-21, 2017b.

Rodríguez R., F.; Palma L., X.; Romo B., Á.; Escobar B., D.; Aragú G., B.; Espinoza O., L.; McMillan L., N. \& Gálvez C., J. Hábitos alimentarios, actividad física y nivel socioeconómico en estudiantes universitarios de Chile. Nutr. Hosp., 28(2):447-55, 2013.

Rodríguez-Rodríguez, F.; Cristi-Montero, C.; González-Ruíz, K.; CorreaBautista, J. E. \& Ramírez-Vélez, R. Bioelectrical impedance vector analysis and muscular fitness in healthy men. Nutrients, 8(7):407, 2016.

Rodríguez, F. \& Almagià, A. Evaluación y Ciencia de la Morfoestructura Humana. Valparaíso, Ediciones Universitarias de Valparaíso, 2016.

Said, M.; Lamya, N.; Olfa, N. \& Hamda, M. Effects of high-impact aerobics vs. Low-impact aerobics and strength training in overweight and obese women. J. Sports Med. Phys. Fitness, 57(3):278-88, 2017.

Silva, R. F.; Cadore, E. L.; Kothe, G.; Guedes, M.; Alberton, C. L.; Pinto, S. S.; Pinto, R. S.; Trindade, G. \& Kruel, L. F. M. Concurrent training with different aerobic exercises. Int. J. Sports Med., 33(8):627-34, 2012.

Skrypnik, D.; Bogdan'ski, P.; Ma dry, E.; Karolkiewicz, J.; Ratajczak, M.; Krys'ciak, J.; Pupek-Musialik, D. \& Walkowiak, J. Effects of endurance and endurance strength training on body composition and physical capacity in women with abdominal obesity. Obes. Facts, 8(3):175-87, 2015.

Stewart, A.; Marfell-Jones, M.; Olds, T. \& De Ridder, J. International Standards for Anthropometric Assessment. Lower Hutt, International Society for the Advancement in Kinanthropometry, 2011.

Swift, D. L.; McGee, J. E.; Earnest, C. P.; Carlisle, E.; Nygard, M. \& Johannsen, N. M. The effects of exercise and physical activity on weight loss and maintenance. Prog. Cardiovasc. Dis., 61(2):206-13, 2018.

Tanaka, H.; Monahan, K. D. \& Seals, D. R. Age-predicted maximal heart rate revisited. J. Am. Coll. Cardiol., 37(1):153-6, 2001.

Watson, K. \& Baar, K. MTOR and the health benefits of exercise. Semin. Cell Dev. Biol., 36:130-9, 2014.

Westcott, W. L. Resistance training is medicine: effects of strength training on health. Curr. Sports Med. Rep., 11(4):209-16, 2012.

Willis, L. H.; Slentz, C. A.; Bateman, L. A.; Shields, A. T.; Piner, L. W.; Bales, C. W.; Houmard, J. A. \& Kraus, W. E. Effects of aerobic and/or resistance training on body mass and fat mass in overweight or obese adults. J. Appl. Physiol., 113(12):1831-7, 2012.

Wilms, B.; Frick, J.; Ernst, B.; Mueller, R.; Wirth, B. \& Schultes, B. Whole body vibration added to endurance training in obese women - A pilot study. Int. J. Sports Med., 33(9):740-3, 2012.

World Medical Association. World Medical Association Declaration of Helsinki: Ethical principles for medical research involving human subjects. JAMA, 310(20):2191-4, 2013.
Corresponding author:

Rodrigo Alejandro Yáñez Sepúlveda

Escuela de Educación

Pedagogía en Educación Física

Universidad Viña del Mar

Avenida Agua Santa № 7055

Viña del Mar

PC:2520000

CHILE

E-mail: rodrigo.yanez@pucv.cl

Received: 06-07-2021

Accepted: 22-08-2021 